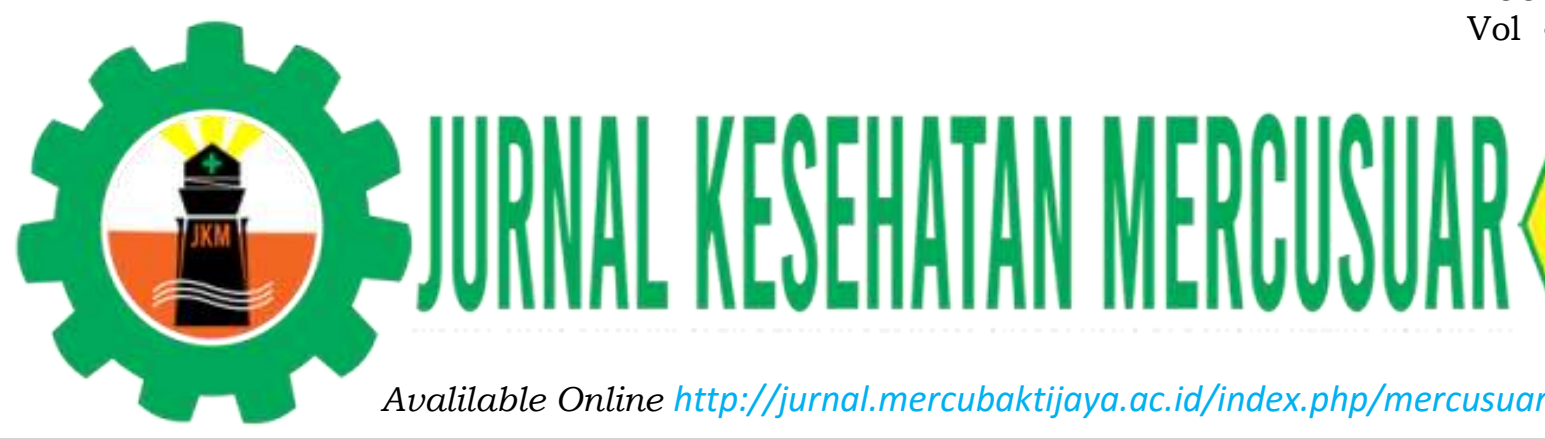

\title{
PENGARUH EDUKASI ONLINE BERBASIS FAMILY CENTERED MATERNITY CARE TERHADAP SELF EFFICACY IBU POSTPARTUM DALAM PEMBERIAN ASI EKSKLUSIF
}

\author{
Rini Rahmayanti ${ }^{*}$, Dedi Adha ${ }^{2}$, Fitri Wahyuni $\mathrm{S}^{\mathbf{3}}$ \\ ${ }^{1 * 2,3}$ Program Studi SI Keperawatan STIKes MERCUBAKTIJAYA Padang, Kota Padang, Sumatera Barat \\ *Email korespondensi: rinie.rahmayanti@gmail.com
}

\begin{abstract}
The coverage of exclusive breastfeeding for infants aged 0-5 months in Indonesia in 2018 is only 37.3\%. Self-efficacy is one of the main factors affecting the behavior of exclusive breastfeeding. During the Covid-19 pandemic, the self-efficacy of mothers for breastfeeding decreased, so increasing efforts are needed. Increasing knowledge can be done by providing online education based on family centered maternity care (FCMC). The purpose of this study was to determine the effect of FCMC-based online education on the self-efficacy of postpartum mothers in exclusive breastfeeding. This type of research is pre-experimental with one group pretest-posttest design with a total sample of 10 postpartum mothers. Data were analyzed using paired t-test. The results showed that the mean self-efficacy before being given online education was 41 with a standard deviation of 4.37, the mean self-efficacy after being given peer education was 59.8 with a standard deviation of 3.4. There is a difference in the mean value before and after the online education intervention was given with $p$-value $=0.000$ ( $p<0.05)$. There is an effect of FCMC-based online education on the self-efficacy of postpartum mothers in breastfeeding. Health servicesare expected to facilitate FCMC-based online education programs to increase self-confidence in breastfeeding.
\end{abstract}

Keywords : Postpartum mothers, breastfeeding, self efficacy, online education, FCMC

\begin{abstract}
ABSTRAK
Cakupan pemberian ASI eksklusif pada bayi usia 0-5 bulan di Indonesia tahun 2018 hanya 37,3\%. Self efficacy merupakan salah satu faktor utama yang mempengaruhi perilaku pemberian ASI eksklusif. Selama pandemi Covid-19, efikasi diri ibu untuk menyusui menurun sehingga diperlukan upaya peningkatan. Peningkatan pengetahuan dapat dilakukan dengan memberikan pendidikan online berbasis family centered maternity care (FCMC). Tujuan penelitian ini adalah untuk mengetahui pengaruh pendidikan online berbasis FCMC terhadap efikasi diri ibu postpartum dalam pemberian ASI eksklusif. Jenis penelitian yang digunakan adalah pra eksperimental dengan rancangan one group pretest-posttest design dengan jumlah sampel sebanyak 10 orang ibu postpartum. Data dianalisis menggunakan uji-t berpasangan. Hasil penelitian menunjukkan bahwa rata-rata efikasi diri sebelum diberikan pendidikan online adalah 41 dengan standar deviasi 4,37, rata-rata efikasi diri setelah diberikan pendidikan sebaya adalah 59,8 dengan standar deviasi 3,4. Ada perbedaan nilai rata-rata sebelum dan sesudah diberikan intervensi pendidikan online dengan $p$-value $=0,000(\mathrm{p}<0,05)$. Ada pengaruh pendidikan online berbasis FCMC terhadap efikasi diri
\end{abstract}


ibu postpartum dalam menyusui. Pelayanan kesehatan diharapkan dapat memfasilitasi program edukasi online berbasis FCMC untuk meningkatkan rasa percaya diri dalam menyusui.

Kata Kunci : Ibu nifas, menyusui, self efficacy, pendidikan online, FCMC

\section{PENDAHULUAN}

Inisiasi menyusu dini dan menyusui secara eksklusif membantu anak-anak bertahan hidup dan membangun antibodi yang mereka butuhkan agar terlindung dari berbagai penyakit (Pramanik et al, 2020). Pemberian ASI secara eksklusif sampai 6 bulan dan dilanjutkan hingga 2 tahun dapat menurunkan angka kesakitan dan kematian bayi, mengurangi risiko penyakit kronis, dan membantu perkembangan bayi (Kemenkes, 2018).

Cakupan ASI eksklusif Menurut World Health Organization, cakupan ASI eksklusif tahun 2018 di seluruh dunia hanya sekitar $36 \%$ selama periode 2007 2014. Proporsi pemberian ASI ekslusif pada bayi umur 0-5 bulan di Indonesia hanya sebanyak $37,3 \%$, Provinsi dengan proporsi tertinggi pemberian ASI eksklusif pada bayi umur 0-5 bulan adalah Provinsi Kepulauan Bangka Belitung (56,7\%), sedangkan provinsi dengan proporsi terendah adalah Provinsi Nusa Tenggara Barat (20,3\%). dan Sumatera Barat sebesar $35 \%$. kelima dengan cakupan ASI eksklusif 73,6\% (Riskesdas, 2018).

Berdasarkan data Dinas Kesehatan Sumatera Barat tahun 2016, cakupan pemberian ASI eksklusif di Provinsi Sumatera Barat tiga tahun terakhir cenderung mengalami peningkatan, dimana pada tahun 2014 cakupan pemberian ASI eksklusif adalah 67,4\% dengan target 75,0\%, tahun 2015 cakupannya adalah $72,5 \%$ dengan target 80,0\%, dan cakupan ASI eksklusif tahun 2016 adalah $75,1 \%$ dengan target $83,0 \%$. Pemberian ASI eksklusif masih dibawah target yang telah ditetapkan.
Cakupan ASI di Puskesmas Kota Padang, tiga Puskesmas dengan angka ASI Eksklusif terendah di Puskesmas Air Dingin sebesar 33,8\%, Puskesmas Alai 55,2\% dan Puskesmas Anak Air 55,3\%. Data yang diperoleh dari Dinas Kesehatan Kota Padang (2016), angka pemberian ASI Eksklusif di Kota Padang belum mencapai target $80 \%$. Penurunan ASI dapat terjadi penurunan pada tahun 2020 akibat kondisi pandemi Covid 19 yang telah terjadi secara global di seluruh dunia.

Pemberian ASI yang tidak mencapai target dapat berdampak buruk pada kesehatan bayi. Pertumbuhan dan perkembangan bayi dan balita sangat ditentukan oleh jumlah air susu ibu (ASI) yang diperoleh, termasuk energi dan zat gizi lainnya yang terkandung di dalam ASI. Menyusui dapat mencegah 1/3 kejadian infeksi saluran pernapasan atas (ISPA), kejadian diare dapat turun $50 \%$, dan penyakit usus parah pada bayi prematur dapat berkurang kejadiannya sebanyak 58\%. Pada ibu, risiko kanker payudara juga dapat menurun 6-10\% (Fadhila \& Ninditya, 2016). Dampak tersebut dapat diminimalkan dengan mengupayakan usaha promotif dan persuasif untuk meningkatkan keyakinan diri dan motivasi memberikan ASI.

Beberapa usaha yang dilakukan oleh pemerintah untuk meningkatkan angka pemberian ASI antara lain mengatur dalam Peraturan Pemerintah No. 33 Tahun 2012 tentang pemberian ASI, mencanangkan tanggal 1-7 Agustus setiap tahunnya diperingati sebagai pekan menyusui sedunia yang telah menjadi tujuan global. Berbeda dengan tahun 
sebelumnya, pekan menyusui sedunia pada tahun 2020 dirayakan pada kondisi pandemi Covid-19. UNICEF dan WHO menyerukan pemerintah dan pemangku kepentingan agar mendukung semua ibu menyusui di Indonesia selama Covid-19. Pemerintah diharapkan mempertahankan dan mempromosikan akses kepada layanan yang memungkinkan para ibu untuk tetap menyusui selama masa pandemi (WHO, 2020).

Masa Pandemi Covid-19 yang berlangsung selama hampir 8 bulan berdampak pada semua aspek termasuk angka pemberian ASI di Indonesia. Menurut WHO tahun 2020, akibat pandemi COVID-19, akses kepada layanan esensial seperti konseling menyusui di rumah sakit, klinik kesehatan dan melalui kunjungan ke rumah telah terganggu. Informasi tidak tepat yang beredar tentang keamanan menyusui telah menurunkan angka ibu menyusui karena para ibu postpartum takut menularkan penyakit kepada bayi mereka. Selain itu, ibu juga tidak bisa berbagi pengalaman dengan kelompok pendukung terkait pemberian ASI karena mematuhi protokol kesehatan selama pandemi.

The World Alliance for Breastfeeding Action (WABA) tahun 2013 telah menyatakan keberhasilan menyusui seorang ibu memerlukan dukungan keluarga, teman, masyarakat dan pemerintah. Faktor yang mempengaruhi pemberian ASI eksklusif berupa dukungan berbagai pihak mampu mengurangi berbagai tantangan ibu menyusui dan mengatasi keraguan ibu untuk menyusui bayi. Keyakinan dan persepsi ibu tentang kepuasan bayi saat menyusu merupakan faktor determinan positif paling kuat yang mempengaruhi keberhasilan pemberian ASI eksklusif. Terdapat hubungan signifikan antara self efficacy ibu dalam proses pemberian ASI dengan persepsi ibu akan kekurangan ASI untuk memenuhi kebutuhan bayinya (Kurniawan, 2013).

Self efficacy (keyakinan diri) merupakan salah satu faktor utama untuk meningkatkan perilaku pemberian ASI eksklusif. Dalam menyusui merupakan keyakinan ibu untuk menilai diri akan kemampuannya untuk menyusui bayinya. Faktor yang mempengaruhi self efficacy meliputi pencapaian prestasi (performance accomplishment), pengalaman orang lain (vicarious experiences), persuasi verbal (verbal persuasion), dan respon psikologis (physiological responses) (Dennis, 2010). Pada masa pandemi COVID-19 ini, self efficacy ibu menyusui dapat menurun karena faktor pembentuknya tidak dapat tercapai dengan maksimal seperti tidak mendapatkan pengalaman orang lain, kurangnya persuasi verbal dan respon psikolgis yang menurun. Kepercayaan diri (self efficacy) ibu yang merasa tidak mampu memberikan ASI menjadi faktor utama ibu tidak memberikan ASI secara eksklusif atau menghentikan pemberian ASI sebelum waktunya (Fata \& Rahmawati, 2016).

Peran dan dampak dari Self efficacy cukup besar terhadap praktik pemberian ASI, sehingga perlu adanya upaya untuk meningkatkan self efficacy ibu untuk menyusui. Self efficacy dipengaruhi oleh pengetahuan ibu tentang pemberian ASI. Peningkatan pengetahuan dapat dilakukan dengan pemberian edukasi online berbasis family centered maternity care. Edukasi ini dirancang dengan tetap memperhatikan protokol kesehatan selama masa pandemi COVID-19. Edukasi online dilakukan dengan aplikasi Zoom Cloud Meeting dan WhatsApp Meseenger karena aplikasi ini mudah diakses dan dapat dipahami oleh ibu postpartum. 
Rini Rahmayanti ${ }^{*}$, Dedi Adha ${ }^{2}$, Fitri Wahyuni $S^{3}$ PENGARUH EDUKASI ONLINE BERBASIS FAMILY CENTERED MATERNITY CARE TERHADAP SELF EFFICACY IBU POSTPARTUM DALAM PEMBERIAN ASI EKSKLUSIF

Family centered maternity care merupakan konsep pemberian asuhan keperawatan maternitas yang berpusat pada keluarga (Asmuji \& Indriyani, 2016). Edukasi yang diberikan kepada ibu postpartum dengan didampingi oleh keluarga seperti suami atau orangtua sebagai sistem pendukung ibu dalam pemberian ASI ekslusif. Ibu dengan dukungan keluarga melalui pendekatan FCMC diharapkan memiliki kemampuan yang optimal dalam beradaptasi secara maternal pada masa nifas, juga kemampuan dalam mengasuh bayi (Clay \& Parsh, 2014). Penelitian Sulistyowati tahun 2011 tentang penerapan konsep family centered maternity care terhadap tingkat pengetahuan perawatan bayi dan kemandirian pada ibu postpartum, didapatkan hasil bahwa edukasi dengan konsep family centered maternity care meningkatkan pengetahuan ibu postpartum tentang perawatan bayi. Melalui edukasi berbasis FCMC, keluarga menjadi lebih optimal dalam memenuhi tugas perkembangan keluarga dengan ibu nifas baik melakukan perawatan diri maupun perawatan bayinya (Asmuji. \& Diyan, 2014).

Cakupan ASI di Puskesmas Kota Padang berdasarkan data Dinas Kesehatan Kota Padang tahun 2018, bayi yang berumur 0-6 bulan yang tercatat dalam register pencatatan pemberian ASI tahun 2018 adalah sebanyak 9.976 orang dan mendapat ASI ekslusif sebanyak 7.580 (75,98\%). Dari 23 Puskesmas, tiga Puskesmas dengan angka ASI eksklusif terendah terdapat di Puskesmas Andalas sebesar 58,79 \%, Puskesmas Ulak Karang sebesar 59,48 \% dan Puskesmas Bungus sebesar 63,64 \%. Sedangkan untuk Puskesmas Lubuk Begalung 88,96\%. Pemberian ASI dapat menurun pada tahun 2020 disebabkan oleh kondisi pandemi COVID-19 yang terjadi secara global diseluruh dunia sehingga dibutuhkan usaha untuk meningkatkan keyakinan diri (Self efficacy).

\section{METODE}

Penelitian ini menggunakan desain pra eksperimental dengan pendekatan desain one-group pre-post test. Sebelum intervensi diberikan pre-test dan setelah intervensi diberikan post-test. Intervensi diberikan 4 kali seminggu selama 1 minggu menggunakan aplikasi zoom cloud meeting. Populasi dalam penelitian ini adalah seluruh ibu nifas yang memberikan ASI pada bayinya di wilayah kerja Puskesmas Lubuk Begalung Padang. Jumlah sampel 10 orang dengan Kriteria inklusi adalah bersedia menjadi responden, masuk dalam kategori ibu early postpartum (24 jam sampai satu minggu setelah persalinan), responden mampu berkomunikasi, melihat, dan mendengar dengan baik Pengambilan sampel dalam penelitian ini adalah teknik non probability sampling yaitu purposive sampling. Peneliti menggunakan kuesioner untuk mengukur efikasi diri ibu pada ibu menyusui sebelum dan sesudah memberikan intervensi edukasi online berbasis family centered maternity care. Kuesioner dimodifikasi ke dalam bentuk google form. Teknik analisis yang digunakan adalah analisis univariat yang digunakan untuk melihat efikasi diri ibu menyusui sebelum dan sesudah diberikan intervensi dan analisis bivariat untuk melihat pengaruh pendidikan online berbasis family centered maternity care terhadap efikasi diri menggunakan paired $t$-test karena data berdistribusi normal. 
HASIL DAN PEMBAHASAN

Analisa Univariat

Tabel 1.

Self Efficacy Ibu Postpartum dalam

Pemberian ASI Sebelum diberikan Edukasi Online Berbasis FCMC

\begin{tabular}{llllll}
\hline \multicolumn{1}{c}{$\begin{array}{c}\text { Self } \\
\text { Efficacy }\end{array}$} & n & Mean & Min & Max & SD \\
\hline Rata-Rata & 10 & 41 & 34 & 50 & 4.3 \\
sebelum & & & & & \\
diberikan & & & & & \\
edukasi & & & & & \\
online & & & & & \\
berbasis & & & & & \\
FCMC & & & & & \\
\hline
\end{tabular}

Berdasarkan tabel 1 dari 10 orang responden didapatkan rata-rata self efficacy sebelum dberikan edukasi online berbasis family centered maternity care adalah 41 dengan standar deviasi 4,3 serta nilai minimum 41 dan nilai maksimum 50.

Berdasarkan tabel 1, dari 10 orang responden didapatkan rata-rata self efficacy sebelum diberikan edukasi online berbasis family centered maternity care adalah 41 dengan standar deviasi 4,37 serta nilai minimum 41 dan nilai maksimum 50.

Hasil penelitian ini hampir sama dengan penelitian Riyanti (2018) tentang pengaruh edukasi breastfeeding ibu post partum terhadap breasfeeding self efficacy didapatkan rata-rata self efficacy sebelum diberikan intervensi edukasi adalah 30,27. Hal ini dapat terjadi karena pada penelitian Riyanti (2018) menggunakan sampel yang sama yaitu ibu postpartum yang memberikan ASI kepada bayi. Self efficacy mempunyai pengaruh yang kuat pada perilaku. Orang dengan efikasi diri yang tinggi untuk memperoleh suatu keterampilan atau melaksanakan suatu tugas akan berpartisipasi secara lebih siap, bekerja lebih keras, lebih tekun dalam kesulitan, dan mencapai tingkat hasil yang lebih tinggi. Namun self-efficacy yang tinggi tidak akan kompeten bila pengetahuan dan keterampilan yang dibutuhkan kurang (Santrock, 2012).

\section{Tabel 2.}

\section{Self Efficacy Ibu Postpartum dalam} Pemberian ASI Setelah diberikan Edukasi Online Berbasis Family Centered Maternity Care

\begin{tabular}{llllll}
\hline \multicolumn{1}{c}{$\begin{array}{l}\text { Self } \\
\text { Efficacy }\end{array}$} & n & Mean & Min & Max & SD \\
\hline Rata- & 10 & 59.8 & 55 & 67 & 3.4 \\
Rata & & & & & \\
setelah & & & & & \\
diberikan & & & & & \\
edukasi & & & & & \\
online & & & & & \\
berbasis & & & & & \\
FCMC & & & & \\
\hline
\end{tabular}

Berdasarkan tabel 2 dari 10 orang responden didapatkan rata-rata self efficacy setelah diberikan edukasi online berbasis family centered maternity care adalah 59.8 dengan standar deviasi 3.4 serta nilai minimum 55 dan nilai maksimum 67.

Penelitian ini sejalan dengan penelitian Pradinie (2015) tentang pengaruh paket edukasi breastfeeding self efficacy dan keberhasilan menyusui pada ibu postpartum setelah diberikan intervensi diperoleh 49,5. Menurut analisa peneliti, setelah diberikan intervensi edukasi online berbasis family centered maternity care didapatkan peningkatan self efficacy dalam menyusui lebih tinggi dibandingkan tanpa pendampingan suami (family centered maternity care). Hal ini menunjukkan bahwa pemberian edukasi online berbasis family centered maternity care lebih dapat meningkatkan self efficacy.

Self efficacy merupakan keyakinan yang dimiliki oleh individu terhadap suatu hal yang belum dilakukan sehingga dapat menjadi indikator seseorang dalam menentukan pilihan dan memotivasi diri sendiri agar berhasil dalam mencapai tujuan tindakan yang akan dilakukan (Bandura, 1994). 
Rini Rahmayanti ${ }^{*}$, Dedi Adha ${ }^{2}$, Fitri Wahyuni $\mathbf{S}^{3} \mid$ PENGARUH EDUKASI ONLINE BERBASIS FAMILY CENTERED MATERNITY CARE TERHADAP SELF EFFICACY IBU POSTPARTUM DALAM PEMBERIAN ASI EKSKLUSIF

Analisa Bivariat

Tabel 3.

Pengaruh Edukasi Online Berbasis Family Centered Maternity Care terhadap Self Efficacy Ibu Postpartum dalam Pemberian ASI Sebelum dan Sesudah Diberikan Intervensi

\begin{tabular}{llllll}
\hline \multicolumn{1}{c}{ Self Efficacy } & n & Mean & SD & Selisih mean & p \\
\hline $\begin{array}{l}\text { sebelum diberikan edukasi } \\
\text { online berbasis family }\end{array}$ & & 41 & & & \\
centered maternity care & & & & & \\
\hline & & & 4.10 & 18.8 & 0.000 \\
\hline $\begin{array}{l}\text { Rata-rata setelah diberikan } \\
\text { edukasi online berbasis }\end{array}$ & & & & & \\
family centered maternity \\
care
\end{tabular}

Berdasarkan tabel 3 diatas, dapat dilihat bahwa 10 orang dari responden yang mendapatkan intervensi edukasi online mengalami peningkatan motivasi dengan selisih mean 18.8 sedangkan hasil uji statistik dengan uji paired T-test didapatkan $\mathrm{p}=0,000 \quad(\mathrm{p}<0,05)$, artinya terdapat pengaruh edukasi online berbasis family centered maternity care terhadap self efficacy ibu postpartum dalam pemberian ASI.

Hasil penelitian ini sejalan dengan penelitian Riyanti (2018) tentang pengaruh edukasi breastfeeding ibu post partum terhadap breastfeeding self efficacy. Hasil uji statistik didapatkan nilai $\mathrm{p}=0.000$ maka dapat disimpulkan ada perbedaan yang signifikan antara skor breastfeeding self efficacy pre dengan post. Mete, et al (2010) menunjukkan bahwa ibu yang mengikuti kelas prenatal bersama suaminya memiliki efek yang positif pada praktek menyusui. 80,4\% ibu yang mengikuti kelas prenatal memberikan ASI dengan teknik yang benar. Setelah menyusi, bayi mereka tidur lagi, ibu merasakan dukungan yang tinggi dari pasangan dan memiliki kepercayan diri yang tinggi untuk berhasil menyusui.

Penelitian ini tidak sejalan dengan hasil penelitian yang dilakukan oleh
Pradinie (2015) tentang paket edukasi breastfeeding self efficacy dan keberhasilan menyusui pada ibu postpartum menunjukkan tidak ada perbedaan antara kelompok perlakuan dan kontrol setelah diberikan intervensi paket dukungan menyusui $(\mathrm{p}=0,104)$.

Perbedaan terjadi bisa tejadi karena adanya perbedaan karakteristik sampel. Sampel pada penelitian sebelumnya mayoritas memiliki pengalaman menyusui sebelumnya. Ibu yang telah memiliki pengalaman menyusui secara langsung cenderung lebih percaya diri untuk terus menyusui, apalagi memang sejak awal mayoritas responden memiliki breastfeeding self efficacy yang cukup tinggi sehingga membuat ibu lebih gigih untuk dapat terus menyusui.

Self efficacy pada ibu menyusui sangat penting. Hal tersebut dibuktikan dengan penelitian Zakiah (2012) menyebutkan ibu dengan self efficacy tinggi lebih lama memberikan ASI dibandingkan dengan self efficacy rendah dan terdapat korelasi positif antara self efficacy pada hari pertama post partum dengan lama pemberian ASI pada 2 bulan post partum. Ibu post partum yang memiliki efikasi diri tinggi lebih lama memberikan ASI dibandingkan ibu dengan efikasi rendah. Rata-rata lama 
pemberian ASI saja pada ibu dengan efikasi rendah adalah 34,50 hari, sedangkan rata-rata pada efikasi tinggi sebesar 49,27 hari.

Pada penelitian ini, intervensi dilakukan dengan inovasi dari penelitian sebelumnya. Kombinasi edukasi online dengan konsep family centered maternity care merupakan strategi untuk meningkatkan partisipasi keluarga terkait perawatan ibu postpartum. Family centered maternity care merupakan konsep pemberian asuhan keperawatan maternitas yang berpusat pada keluarga (Asmuji \& Indriyani, 2016). Penelitian ini memberikan pendidikan kesehatan yang menggunakan pendekatan keluarga. Metode ini diharapkan dapat meningkatkan self efficacy ibu dalam pemberian ASI, karena dalam metode ini, dukungan suami bermain peran dalam meningkatkan motivasi dan self efficacy ibu dalam memberikan ASI pada bayinya. Metode online sebagai kombinasi juga mendukung meningkatnya self efficacy, karena rasa nyaman yg bisa muncul karena ibu mendapatkan edukasi di rumah sendiri dan didampingi suami.

Menurut Asmiji \& Indriyani (2016), salah satu jembatan untuk mengoptimalkan upaya edukasi postnatal adalah memang melalui keterlibatan keluarga. Ibu dengan dukungan keluarga melalui pendekatan family centered maternity care diharapkan memiliki kemampuan yang optimal dalam beradaptasi secara maternal pada masa nifas, juga kemampuan dalam mengasuh bayi dan menyusui. Berbagai persepsi yang kurang tepat dalam dua kondisi ini akan sangat berisiko terhadap kesehatan baik ibu maupun bayi. Model ini memiliki keunggulan bahwa dalam mengoptimalkan pemahaman ibu tentang peran dan fungsinya dalam beradaptasi secara maternal dan perawatan bayi baru lahir, keluarga ikut terlibat aktif dalam upaya tersebut. Dampak dari peningkatan pemahaman ibu postpartum tersebut ibu akan memiliki kemampuan competent mothering secara optimal. Hal ini tentunya berkontribusi terhadap optimalisasi status kesehatan ibu maupun bayi yang dilahirkan, sehingga dapat berdampak untuk menekan angka kematian ibu dan bayi.

Hasil penelitian ini juga sesuai dengan teori yang dikemukakan oleh Lunenburg (2011) bahwa breastfeeding self-efficacy dapat dipengaruhi oleh 4 faktor yaitu pencapaian prestasi (performance accomplishment), pengalaman orang lain (vicarious experiences), persuasi verbal (verbal persuasion) dan respon fisiologis (physiological responses). Metode edukasi online dengan konsep family centered maternity care termasuk pada faktor persuasi verbal yang juga dukungan tambahan dari suami yang diharapkan lebih meningkatkan self efficacy. Persuasi verbal merupakan dukungan dari orang lain yang berpengaruh seperti teman, keluarga, konsultan laktasi, dan praktisi kesehatan. Penguatan atau saran yang diberikan oleh orang-orang yang berpengaruh menjadi sumber kekuatan ibu untuk menyusui bayinya.

Hasil penelitian ini juga membuktikan teori Dennis (2010) yang menerangkan bahwa terdapat 4 sumber yang mempengaruhi breastfeeding self efficacy yaitu: 1) pengalaman menyusui bayi secara langsung; 2) pengalaman tidak langsung yang diperoleh melalui pengamatan atau cerita orang lain yang berhasil menyusui; 3) persuasi verbal dari teman, keluarga atau petugas kesehatan tentang laktasi dan 4) respons fisiologis berupa ada tidaknya stres, 
Rini Rahmayanti ${ }^{*}$, Dedi Adha ${ }^{2}$, Fitri Wahyuni $\mathbf{S}^{3}$ PENGARUH EDUKASI ONLINE BERBASIS FAMILY CENTERED MATERNITY CARE TERHADAP SELF EFFICACY IBU POSTPARTUM DALAM PEMBERIAN ASI EKSKLUSIF

keletihan atau kecemasan yang menyertai. Intervensi dalam edukasi online berbasis family centered maternity care yang diberikan pada kelompok perlakuan disusun berdasarkan 4 sumber tersebut, sehingga peningkatan

\section{KESIMPULAN}

Berdasarkan penelitian yang dilakukan didapatkan rata-rata self efficacy ibu dalam pemberian ASI sebelum diberikan edukasi online adalah 41, rata-rata self efficacy ibu dalam pemberian ASI sebelum diberikan edukasi online adalah 59.8, $p$-value = $0,000(\mathrm{p}<0,05)$, yang berarti ada pengaruh edukasi online berbasis family centered maternity care terhadap self efficacy ibu postpartum dalam pemberian ASI eksklusif.

\section{UCAPAN TERIMAKASIH}

Ucapan terima kasih diucapkan kepada Yayasan Mercubaktijaya, STIKes MERCUBAKTIJAYA Padang, Ibu postpartum yang telah bersedia menjadi responden serta pihak terkait yang telah memberikan dukungan dan bantuan dalam pelaksanaan penelitian.

\section{DAFTAR PUSTAKA}

Asmuji., \& Diyan, I. (2014). Model Edukasi Postnatal Melalui Pendekatan Family Centered Maternity Care (FCMC). Jurnal Keperawatan, 5(2), 128-141.

Asmuji., \& Indriyani, D. (2016). Model Family Centered Maternity Care sebagai strategi Optimalisasi Competent Mothering. Ners Airlangga, 11(1), 17-28. https://ejournal.unair.ac.id/JNERS/article/vie w/1905/pdf_17 breastfeeding self efficacy yang ditunjukkan oleh responden dalam kelompok perlakuan membuktikan bahwa teori yang dikemukakan oleh Dennis adalah benar.

Clay, A., \& Parsh, B. (2014). Patient- and family-centered care: not just for kids. Nursing, 44(5), 57-58. https://doi.org/10.1097/ 01.NURSE.0000445764.18817.d2

Deni Darmawan. (2014). Pengembangan E-Learning teori dan desain. Remaja Rosdakarya.

Dennis, C.-L. (2010). Breastfeeding SelfEfficacy. http://www.cindyleedennis.ca/resear $\mathrm{ch} / 1$-breastfeeding/breastfeedingself-efficacy/

Fadhila, S. R., \& Ninditya, L. (2016). Dampak Dari Tidak Menyusui Di Indonesia.

https://www.idai.or.id/artikel/klinik/ asi/dampak-dari-tidak-menyusui-diindonesia

Fata, U. H., \& Rahmawati, A. (2016). Prenatal Education as an Effort In Enhancing Breastfeeding Self Efficacy. Jurnal Ners Dan Kebidanan (Journal of Ners and Midwifery), 3(2), 136-141. https://doi.org/10.26699/jnk.v3i2.art. p136-141

Kemenkes. (2018). Menyusui Sebagai Dasar Kehidupan. Kementerian Kesehatan RI, 1-7.

Kodrat, L. (2010). Dahsyatnya ASI \& Laktasi Untuk Kecerdasaan. Buah Hati Anda. Media Baca.

Kurniawan, B. (2013). Determinan Keberhasilan Pemberian Air Susu Ibu Eksklusif. Jurnal Kedokteran Brawijaya, 27(4), 236-240. https://doi.org/10.21776/ub.jkb.2013 .027 .04 .11 
Rini Rahmayanti ${ }^{*}$, Dedi Adha ${ }^{2}$, Fitri Wahyuni $S^{3}$ PENGARUH EDUKASI ONLINE BERBASIS FAMILY CENTERED MATERNITY CARE TERHADAP SELF EFFICACY IBU POSTPARTUM DALAM PEMBERIAN ASI EKSKLUSIF

Lunenburg, F. C. (2011). Self Efficacy in the workplace: implication for Motivation and Performance. Journal of Management, 14(1), 154 157. https://doi.org/10.1007/978-14419-6868-5

Maryunani, A. (2012). Inisiasi Menyusu Dini, Asi Eksklusif dan Manajemen Laktasi. Trans Info Media.

Mulyani, S. (2013). Asi dan Pedoman Ibu Menyusui. Nuha Medika : Jakarta

Notoadmojo. (2012). Promosi Kesehatan. Rineka Cipta : Jakarta

Pradanie, R. (2015). Paket Dukungan Terhadap Breastfeeding Self Efficacy Dan Keberhasilan Menyusui Pada Ibu Postpartum. Ners, 10(1), 20-29. https://doi.org/http://dx.doi.org/10.2 0473/\%oj.Ners101\% y20-29

Pramanik, Y. R., Sumbara, \& Sholihatul, R. (2020). Hubungan Self-Efficacy Ibu Menyusui Dengan Pemberian Asi Ekslusif. Jurnal Ilmiah Kesehatan Iqra, 8(1), 39-44.

Riskesdas. (2018). Hasil Utama Riset Kesehata Dasar (RISKESDAS). Journal of Physics A: Mathematical and Theoretical, 44(8), 1-200. https://doi.org/10.1088/17518113/44/8/085201

Santrock, J. W. (2012). Psikologi Pendidikan. Salemba Humanika : Jakarta

WHO. (2020). Pekan Menyusui Dunia: UNICEF dan WHO menyerukan
Pemerintah dan Pemangku Kepentingan agar mendukung semua ibu menyusui di Indonesia selama COVID-19. https://www.who.int/indonesia/news /detail/03-08-2020-pekan-menyusuidunia-unicef-dan-who-menyerukanpemerintah-dan-pemangkukepentingan-agar-mendukungsemua-ibu-menyusui-di-indonesiaselama-covid-19 